\title{
IMPROVING THE PERFORMANCE OF ASPHALT CONCRETE MIXTURES WITH POL YMER ASPHALT IN SUBMERGED FLOODS
}

\author{
Yanuar Setiawan' ${ }^{1}$ Erlina Yanuarini², Nunung Martina ${ }^{3}$, \\ Muhammad Fathur Rouf Hasan ${ }^{4}$, Rinawati ${ }^{5}$ \\ 1,2,3,4,5 Jurusan Teknik Sipil, Politeknik Negeri Jakarta, Kota Depok, 16424, Indonesia \\ e-mail : yanuar.setiawan@sipil.pnj.ac.id ${ }^{1}$
}

\begin{abstract}
The road conditions which is always submerged can reduce the performance of the asphalt pavement. This research was conducted to obtain the characteristics of polymer asphalt concrete against flooding. Marshall testing was carried out on conventional and polymer asphalt concrete with optimum asphalt content treated with water immersion in variations of 0 days, 0.5 days, 1 day, 2 days, and 4 days. The results show polymer asphalt can improve the durability of asphalt concrete which is submerged in floodwater. This is indicated by the difference in the stability value of $113 \%$ in the variation of immersion for 4 days.
\end{abstract}

Keywords: Asphalt Concrete; Flood; Durability; Polymer Asphalt

\section{INTRODUCTION}

The development of the number of motorized vehicles impacts transportation routes and road infrastructure (Martina et al., 2019). High traffic volume and long vehicle loads lead to premature damage and reduced road structures durability (Jiang et al., 2018). The paved road infrastructure's ability will reach the planned roadworthiness life and will naturally decrease over time. The increase in road damage types can indicate the decrease in inroads' ability to carry out their functions. The road damage can occur by excessive loads, quality of construction, and natural disasters, one of which is flooding.

Flood is one of the disasters that often occurs in Indonesia. Significant damage and losses, especially in the infrastructure sector, are resulted in floods. Floods result in stagnant water on road infrastructure. Based on the information we summarize from the website of the National Disaster Management Agency (BNPB), flood events from early January to August 2020 have been recorded 726 times ((BNPB). Humidity on asphalt is one of the most critical factors affecting the durability of asphalt pavements (Rẑek et al., 2020).

Road conditions that are always submerged can reduce the performance of the asphalt pavement such as the value of stability, cavities between grains or less dense mixtures and affect its durability. Based on this, the asphalt concrete mixture requires a good binder so that the durability of the asphalt can be maintained. According to Khoeini, et al, 2019 the addition of polymers to asphalt provides additional strength in a humid environment (Khoeini et al., 2019). Meanwhile, according to Celauro, et al, (2019) the addition of polymers can increase rutting resistance, high-temperature stiffness, susceptibility to temperature variations, 
and also fatigue cracking resistance (Celauro et al., 2019).

Asphalt with an added polymer material which is elastomeric (Elvaloy) can increase the durability of road pavements and the stability of the asphalt concrete mixture. The polymer asphalt used in this research is elvaloy polymer asphalt. Elvaloy is a Reactive Ethylene Terpolymer (RET) which chemically reacts with asphalt. The addition of Elvaloy RET significantly increases the stiffness of asphalt and the resistance of the asphalt to ruts and fatigue properties, without causing serious damage. (Geckil \& Seloglu, 2018). One of the Elvaloy polymer asphalt in Indonesia is known as JAP57 Polymer Asphalt.

The value of durability and pavement in the Elvaloy asphalt mixture will be higher than the mixture without using Elvaloy asphalt (Geckil \& Seloglu, 2018). This is because the addition of an Elvaloy polymer material increases the bonds between the aggregates in the mixture which can withstand greater loads. The use of asphalt with Elvaloy modified materials can increase the performance of the asphalt concrete mixture and can reduce deformation or deformation of the pavement (Jasso et al., 2015). The use of polymer modifications for asphalt concrete mixtures has proven to be quite efficient in increasing the roadworthiness life, as research conducted by Diab et al, (2019) stated that polymer modification had a positive effect on Indirect Tensile Strength (ITS), creep strain, recovery ratio, resilient modulus, resistance to moisture damage, and fatigue life (Diab et al., 2019).

This research aims to compare the characteristic values between conventional asphalt concrete mixture and polymer asphalt concrete mixture with water immersion. This research was conducted by making Marshall specimens with variations of the asphalt used, namely Pen-60/70 Shell asphalt (conventional asphalt) and JAP-57 polymer asphalt.

\section{METHODS}

Experimental research was conducted to determine the characteristics of asphalt concrete with polymer asphalt against floodwater. This research was conducted at the Jakarta State Polytechnic Civil Engineering Laboratory in 2020. The first stage in this research was the preparation and testing of asphalt concrete materials. The next stage is the manufacture of test objects to find optimum contents of conventional asphalt (Shell asphalt) and optimum polymer asphalt (JAP-57), namely Marshall test-Stage 1. By using the optimum conventional asphalt content and optimum polymer asphalt content, then the test object was made, and the test object was immersed with time variations, namely 0 days (without immersion), 0,5 days, 1 day, 2 days, and 4 days with temperature approximately $25{ }^{\circ} \mathrm{C}$. This stable temperature is obtained by using a special soaking tub with a temperature gauge. The next stage is the second stage of Marshall testing.

At the preparation and testing of asphalt concrete materials, all asphalt concrete mix materials, including coarse aggregate, fine aggregate, filler, conventional asphalt, and polymer asphalt must meet the requirements of the specification for each mixture. Indonesian National Standard (SNI) 1969:2008 is used for testing coarse aggregates and SNI 03-4428:1997 for testing for fine aggregates. Meanwhile, for asphalt using SNI 2441:2011 related to the density of asphalt. SNI 2456:2011 
is used as a reference regarding the penetration test, SNI 2432:2011 is related to the ductility test, SNI 2434:2011 is related to the softening point test.

The fine aggregate used has bulk specific gravity of 2,210, SSD specific gravity of 2,481, apparent specific gravity of 3.037 , water absorption of $12.23 \%$, and sand equivalent of $76.2 \%$.

The coarse aggregate used has bulk specific gravity of 2,419 , SSD specific gravity of 2.5, apparent specific gravity of 2,632, and water absorption of $3,335 \%$. The conventional asphalt used has a specific gravity value of 1.04 , a penetration value of 69 , an asphalt softening point of $48.75^{\circ} \mathrm{C}$, and a ductility of $106 \mathrm{~cm}$. The polymer asphalt used has a specific gravity value of 1.034 , a penetration value of 47 , a softening point of asphalt of $50.25^{\circ} \mathrm{C}$, and a ductility of $147.5 \mathrm{~cm}$.

The composition of the mixture used in this study was $40 \%$ coarse aggregate of total aggregate weight, $56 \%$ of fine aggregate of total weight of aggregate, $4 \%$ of filler of total weight of aggregate. The filler used is Portland Cement type I.

In this study, using 5 variations of asphalt content of $4.5 \%, 5 \%, 5.5 \%, 6 \%$, and $6.5 \%$ for conventional asphalt concrete and polymer asphalt concrete as shown in Table 1 . The range of asphalt content variations with an increase of $0.5 \%$ has been carried out in previous studies, but with variations in asphalt content of $4 \%, 4.5 \%, 5 \%, 5.5 \%$, $6 \%$ (Yin et al., 2020). In this study, the total test specimens used for the first Marshall Test were 30. After obtaining the optimum asphalt value for conventional asphalt concrete mixtures and polymer asphalt concrete mixtures, a test object was made for the second stage of the Marshall test. A total of 3 specimens each were used with immersion variations of 0 days, 0.5 day, 1 day, 2 days, and 4 days; see Table 2 . A total of 30 specimens were used for the second phase of Marshall testing. At this stage, 15 specimens are used for conventional asphalt concrete mixtures and 15 specimens for polymer asphalt concrete mixtures. After obtaining the Marshall properties from the second phase of Marshall testing, it will be continued by analyzing results.

Previous researchers have previously conducted the variation of the same asphalt content to find the optimum asphalt content. The number of specimens used to find the optimum asphalt content is the same for each variation using three specimens to follow the regulations. The variation of the length of immersion has also been carried out in previous studies with variations of immersion duration of 0.5 days, 1 day, 2 days, and 3 days (Setiadji, 2016). However, in this research, the time variations used were 0 days, 0.5 days, 1 day, 2 days, and 4 days. The different immersion times will impact the behavior of conventional asphalt concrete mixtures and polymer asphalt concrete mixtures.

The Marshall test- Stage 2 is carried out on each specimen group as soon as the immersion time ends. For 0 day immersion, the test object is not immersed but will be immediately weighed and test in Marshall test-Stage 2. For 0.5 days of immersion, after the specimens are immersed for 0.5 days of immersion, immediately weighed, and tested in Marshall test-Stage 2, as well as for the specimens immersed for 1 day, 2 days, and 4 days. This method of immersed was conducted in previous research. By conducting the Marshall test-stage 2, the asphalt stability values for conventional asphalt concrete 
mixtures and polymer asphalt concrete mixtures will be obtained.

\section{RESULTS AND DISCUSSION}

\section{Optimum Asphalt Content}

Conventional asphalt concrete mixture specimens (Shell Asphalt) and polymer asphalt concrete mixture specimens (JAP-57) with variations of asphalt content $4.5 \%, 5 \%, 5.5 \%, 6 \%, 6.5 \%$ were tested by Marshall test to get the optimum asphalt content value. The Marshall test results are shown in Table 3 and Table 4. The optimum asphalt content obtained is used as a fixed variable in the second phase of the Marshall test, where at that stage it will be used to test the variable flood immersion time.

When compared with the specification requirements for continuously graded hot asphalt mixtures in SNI 8198: 2015, the results of the Void in Mineral Aggregate (VMA), Void Filled with Bitumen (VFB) values and stability of all variations in the ratio of asphalt content in conventional asphalt concrete mixtures meet the requirements. On the other hand, the Void in Mix (VIM) value for the variation of asphalt content of $6 \%$ and $6.5 \%$ does not meet the minimum criteria required. The flow value of the specimens with a variation of asphalt content of $4.5 \%$ and $6.5 \%$ exceeds the maximum limit required. Figure 1 shows that based on the test results, the optimum conventional asphalt content obtained is $5.25 \%$.

Marshall test results for polymer asphalt concrete mixtures (JAP-57) were also compared with the specification requirements for continuously graded hot asphalt mixture in SNI 8198: 2015. VFB values and stability for all variations of polymer bitumen content met the specified requirements. On the other hand, the VMA and VIM values for the variation of the polymer asphalt content of $6 \%$ and $6.5 \%$ were less than the minimum limit required. Flow value for specimen variation of polymer asphalt content of $6.5 \%$ exceeds the maximum limit specified. The optimum polymer asphalt content value obtained based on the results of the test data which can be seen in Figure 2 is $5 \%$.

\section{Flood Immersion Effect}

In the second phase of the Marshall test, specimens were made with the optimum asphalt content obtained from the Marshall test phase one, then immersed in floodwater for 0 days, 0.5 days, 1 day, 2 days, and 4 days. The results of the Marshall test can be seen in Figure 3.

Figure 3 a shows that the effect of the longer the flood immersion results in a decreasing VMA value for both conventional asphalt mixtures and polymer asphalt mixtures. Meanwhile, Figure $3 \mathbf{b}$ shows that the effect of the longer the flood immersion results in an increasing VFB value. This shows that the longer the flood immersion causes the void between the aggregate particles to be filled with asphalt. All VMA and VFB values of all test objects meet the minimum requirements required in SNI 8198: 2015.

Figure 3 c shows that the VIM value decreases with the length of the flood immersion. This shows that the cavity in the specimen is less because the cavity is filled with asphalt. The VIM test results for all specimens are in the zone required by SNI 8198: 2015.

Flow shows the amount of vertical drop in the specimen. The flow results from specimens without immersion and immersion time for 4 days of polymer asphalt mixture and specimens with 4 days immersion time of conventional asphalt mixture exceeding the 
maximum limit required in SNI 8198: 2015 according to Figure 3 e. This indicates that the immersion time resulted in an increase in the flow value of the specimen. However, the test results show that the use of polymer asphalt in the asphalt concrete mixture inhibits melting more with the longer immersion time.

The stability of the specimens with 4 days immersion variation in conventional asphalt mixtures does not meet the minimum requirements specified by SNI 8198: 2015. In Figure $\mathbf{3} \mathbf{d}$ also shows that the value of stability is decreasing due to the length of the flood immersion. However, the stability value of the polymer asphalt mixture has a higher stability value than the stability of conventional asphalt mixtures. In fact, the difference in the stability value of the polymer asphalt mixture was $113 \%$ higher than the conventional asphalt mixture at the 4 days immersion time variation. This is due to the increased stiffness of asphalt when given the addition of Elvaloy compared to conventional asphalt (Geckil \& Seloglu, 2018). Besides, reactive elastomeric terpolymer modified asphalt can improve the longterm stability of asphalt mixture (Chang, 2018).

\section{CONCLUSION}

The optimum content of conventional asphalt (Shell asphalt) was $5.25 \%$ and the optimum level of polymer asphalt (JAP-57) was 5\%. Based on these data, it can be concluded that the use of polymer asphalt is more effective when compared to conventional asphalt because it contains less asphalt but provides test results that meet the requirements of the specification.

The effect of the duration of flood immersion in the specimen is that the
VMA and VIM values are decreasing, offsetting the increasing VFB value. This shows that the longer the immersion decreases the cavity in the specimen where the void is filled with asphalt.

The time factor of flood immersion resulted in decreased specimen stability and increased flow of specimens. this means that the strength and quality of the asphalt mixture decrease due to the effects of flood immersion. However, the use of polymer asphalt in the asphalt mixture improves its durability against the effects of flood immersion. This is obtained from the stability value of the polymer asphalt mixture which is $113 \%$ higher than the conventional asphalt mixture in the 4-day immersion variation, also supported by its lower flow value.

\section{ACKNOWLEDGEMENT}

We would like to thank the Unit Penelitian dan Pengabdian Kepada Masyarakat (UPPM) Politeknik Negeri Jakarta for providing full financial support through the Penelitian Dosen Pemula 2020.

\section{REFERENCES}

Badan Nasional Penanggulangan Bencana (BNPB). (2020). https://bnpb.go.id/berita/banjirbencana-alam-mematikanhingga-agustus-2020. Accessed at September 21, 2020

Celauro, C., Bosurgi, G., Sollazzo, G., \& Ranieri, M. (2019). Laboratory and in-situ tests for estimating improvements in asphalt concrete with the addition of an LDPE and EVA polymeric compound. Construction and Building Materials, 196, 714-726. 
Chang, R. H. L. (2018). Mechanism and Performance of Reactive Elastomeric Terpolymer Modified Asphalt and Asphalt Mixture. Acta Materiae Compositae Sinica, 35(7), 1952-1962. doi:10.13801/j.cnki.fhclxb.20170 925.002

Diab, A., Enieb, M., \& Singh, D. (2019). Influence of aging on properties of polymer-modified asphalt. Construction and Building Materials, 196, 54-65. doi:10.1016/j.conbuildmat.2018.1 1.105 .

Geckil, T., \& Seloglu, M. (2018). Performance properties of asphalt modified with reactive terpolymer. Construction and Building Materials, 173, 262-271. doi:10.1016/j.conbuildmat.2018.0 4.036 .

Jasso, M., Hampl, R., Vacin, O., Bakos, D., Stastna, J., \& Zanzotto, L. (2015). Rheology of conventional asphalt modified with SBS, Elvaloy and polyphosphoric acid. Fuel Processing Technology, 140, 172-179. doi:10.1016/j.fuproc.2015.09.002.

Jiang, Z., Hu, C., Easa, S., Zheng, X., \& Abd El Halim, A. O. (2018). Identifying optimal polymer type of modified asphalt based on damping characteristics. Construction and Building Materials, 173, 308-316. doi:10.1016/j.conbuildmat.2018.0 3.278 .

Khoeini, S., Dessouky, S., Papagiannakis, A. T., Walubita, L. F., Tahami, S. A., \& Gholikhani, M. (2019). Using polymer-based mixes as alternative to asphalt mixes in low volume roads. Construction and Building Materials, 204, 177-183. doi:10.1016/j.conbuildmat.2019.0 1.124 .

Martina, N., Hasan, M. F. R., \& Setiawan, Y. (2019). Pengaruh Serbuk Ban Bekas Sebagai Campuran Agregat Halus Pada Campuran Aspal Porous. Wahana Teknik Sipil: Jurnal Pengembangan Teknik Sipil, 24(2), 144-152.

Ržek, L., Turk, M. R., \& Tušar, M. (2020). Increasing the rate of reclaimed asphalt in asphalt mixture by using alternative rejuvenator produced by tire pyrolysis. Construction and Building Materials, 232, 117177. doi:10.1016/j.conbuildmat.2019.1 1717.

Setiadji, B. H. (2016). Durabilitas Campuran Hot Rolled SheetWearing Course (HRS-WC) Akibat Rendaman Menerus dan Berkalan Air Rob. Jurnal Teknik Sipil, 13(2), 114. doi:10.24002/jts.v13i2.647.

Yin, F., Chen, C., West, R., Martin, A. E., \& Arambula-Mercado, E. (2020). Determining the Relationship Among Hamburg Wheel-Tracking Test Parameters and Correlation to Field Performance of Asphalt Pavements. Transportation Research Record, 2674(4), 281291. doi:10.1177/0361198120912430 
Applied Research on Civil Engineering and Environment (ARCEE) VOL. 02 No. 02, February 2021

\section{Appendix}

Table 1. Specimens Used in the Marshall Test -Stage 1 to Obtain Optimum Asphalt Content

\begin{tabular}{|c|c|c|c|c|}
\hline No & Testing type & $\begin{array}{c}\text { Variations of } \\
\text { asphalt content }\end{array}$ & $\begin{array}{c}\text { Number of } \\
\text { specimens }\end{array}$ & $\begin{array}{c}\text { Total of } \\
\text { specimens }\end{array}$ \\
\hline \multirow{5}{*}{$1 \mathrm{~A}$} & & $(4.5 \%)$ & 3 & \multirow{5}{*}{15} \\
\hline & Marshall Test -Stage 1 with & $(5.0 \%)$ & 3 & \\
\hline & Conventional Asphalt (Shell & $\mathrm{Pb}(5.5 \%)$ & 3 & \\
\hline & Asphalt) & $(6.0 \%)$ & 3 & \\
\hline & & $(6.5 \%)$ & 3 & \\
\hline \multirow{5}{*}{ 1B } & \multirow{5}{*}{$\begin{array}{l}\text { Marshall Test -Stage } 1 \text { with } \\
\text { with optimum Polymer } \\
\text { Asphalt (JAP-57) }\end{array}$} & $(4.5 \%)$ & 3 & \multirow{5}{*}{15} \\
\hline & & $(5.0 \%)$ & 3 & \\
\hline & & $\mathrm{Pb}(5.5 \%)$ & 3 & \\
\hline & & $(6.0 \%)$ & 3 & \\
\hline & & $(6.5 \%)$ & 3 & \\
\hline
\end{tabular}

Tabel 2. Specimens Used in the Marshall Test - Stage 2

\begin{tabular}{|c|c|c|c|c|}
\hline No & Testing type & $\begin{array}{c}\text { Variation of } \\
\text { Immersion Time }\end{array}$ & $\begin{array}{c}\text { Number of } \\
\text { specimens }\end{array}$ & $\begin{array}{c}\text { Total of } \\
\text { specimens }\end{array}$ \\
\hline \multirow{5}{*}{$2 \mathrm{~A}$} & \multirow{5}{*}{$\begin{array}{l}\text { Marshall Test -Stage } 2 \text { with } \\
\text { optimum contents of } \\
\text { Conventional Asphalt (Shell } \\
\text { Asphalt) }\end{array}$} & 0 days & 3 & \multirow{5}{*}{15} \\
\hline & & 0.5 days & 3 & \\
\hline & & 1 day & 3 & \\
\hline & & 2 days & 3 & \\
\hline & & 4 days & 3 & \\
\hline \multirow{5}{*}{$2 \mathrm{~B}$} & \multirow{5}{*}{$\begin{array}{l}\text { Marshall Test -Stage } 2 \text { with } \\
\text { optimum contents of Polymer } \\
\text { Asphalt (JAP-57) }\end{array}$} & 0 days & 3 & \multirow{5}{*}{15} \\
\hline & & 0.5 days & 3 & \\
\hline & & 1 day & 3 & \\
\hline & & 2 days & 3 & \\
\hline & & 4 days & 3 & \\
\hline
\end{tabular}

Table 3. Marshall Properties of Conventional Asphalt Concrete Mixtures

\begin{tabular}{ccccccc}
\hline $\begin{array}{c}\text { Asphalt } \\
\text { Content (\%) }\end{array}$ & VMA (\%) & VFB (\%) & VIM (\%) & Stability (Kg) & Flow (mm) & $\begin{array}{c}\text { Marshall } \\
\text { Quotient } \\
(\mathbf{k g} / \mathbf{m m})\end{array}$ \\
\hline 4.5 & 15.67 & 75.55 & 3.83 & 1762.92 & 4.7 & 380.05 \\
5 & 16.32 & 75.27 & 4.07 & 1772.88 & 3.97 & 449.92 \\
5.5 & 16.06 & 80.63 & 3.27 & 1611.03 & 2.91 & 557.29 \\
6 & 15.47 & 86.90 & 2.65 & 1586.13 & 3.77 & 425.75 \\
6.5 & 16.05 & 86.77 & 2.22 & 1600.24 & 4.37 & 371.19 \\
\hline
\end{tabular}

Table 4. Marshall Properties of Polymer Asphalt Concrete Mixtures

\begin{tabular}{ccccccc}
\hline $\begin{array}{c}\text { Polymer } \\
\text { Asphalt } \\
\text { Content (\%) }\end{array}$ & VMA (\%) & VFB (\%) & VIM (\%) & Stability (Kg) & Flow (mm) & $\begin{array}{c}\text { Marshall } \\
\text { Quotient } \\
\text { (kg/mm) }\end{array}$ \\
\hline 4.5 & 15.04 & 79.31 & 3.11 & 1803.59 & 3.67 & 539.61 \\
5 & 17.02 & 72.74 & 4.88 & 1844.26 & 3.90 & 474.83 \\
5.5 & 16.09 & 79.94 & 3.30 & 1517.24 & 4.00 & 379.52 \\
6 & 14.88 & 90.77 & 1.23 & 1716.44 & 3.90 & 445.95 \\
6.5 & 14.87 & 94.30 & 0.85 & 1709.80 & 4.90 & 358.40 \\
\hline
\end{tabular}


Applied Research on Civil Engineering and Environment (ARCEE) VOL. 02 No. 02, February 2021

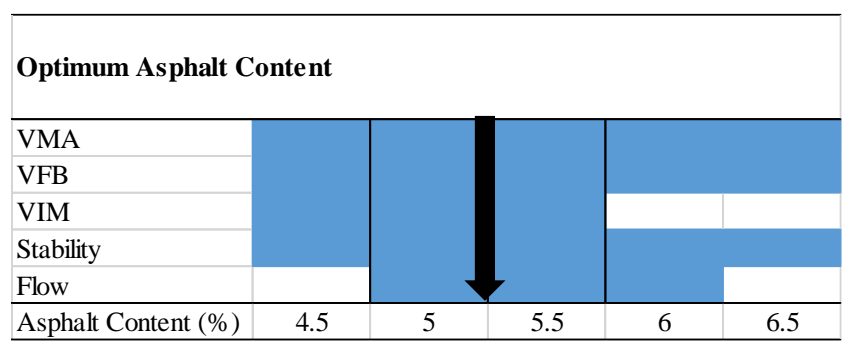

Figure 1. Optimum Conventional Asphalt Content

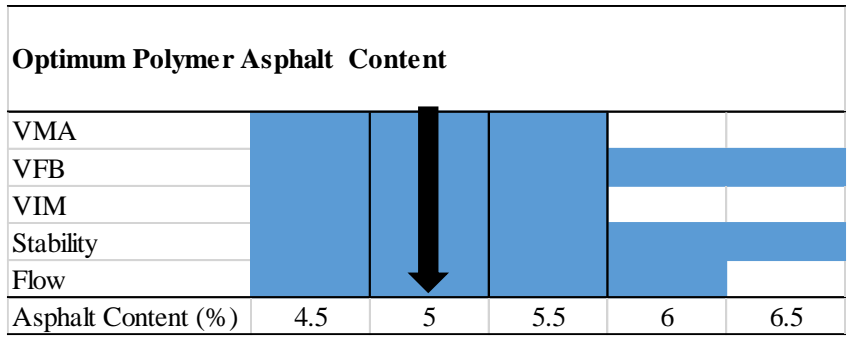

Figure 2. Optimum Polymer Asphalt Content

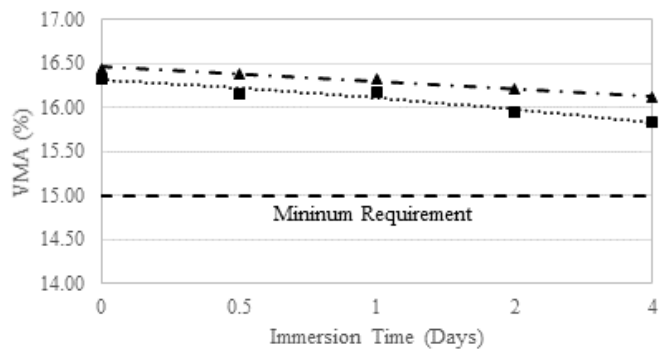

-VMA Asphalt Shell AVMA JAP - 57

(a)

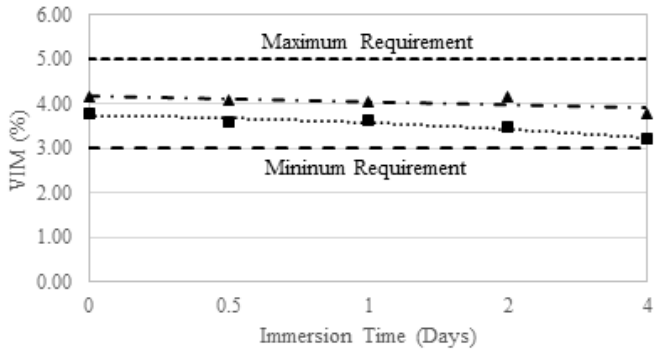

-VIMAsphalt Shell AVIMJAP - 57

(c)

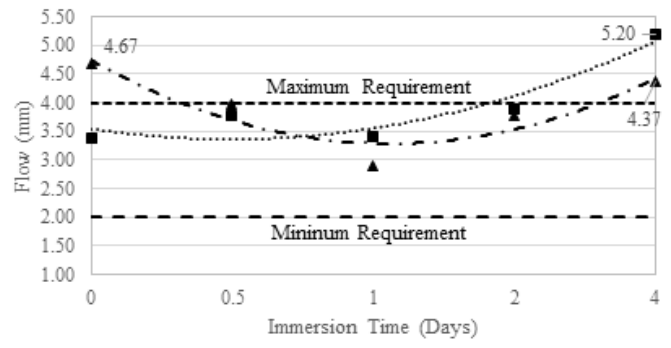

- Flow Asphalt Shell AFlow JAP - 57

(e)

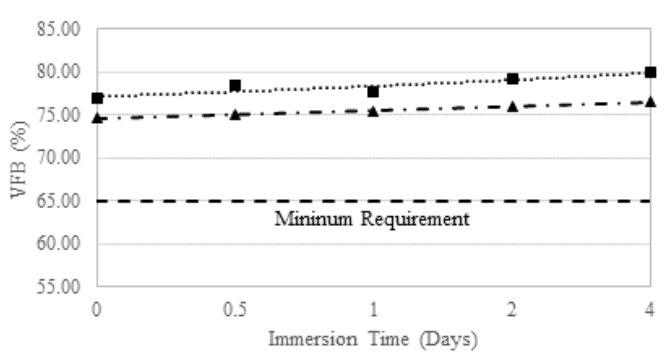

- VFB Asphalt Shell AVFB JAP - 57

(b)

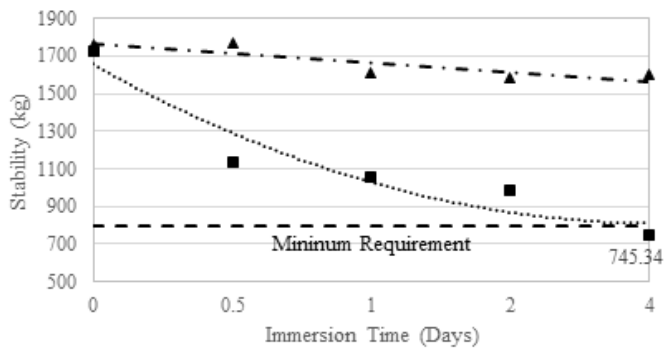

- Stability Asphalt Shell AStability JAP - 57

(d)

Figure 3. Marshall Test of Flood Immersion Variation with Optimum Asphalt Content: a) VMA, b) VFB, c) VIM, d) Stability, e) Flow 